\title{
HUBUNGAN PERSEPSI KESERIUSAN PENYAKIT WANITA PASANGAN USIA SUBUR TENTANG INSPEKSI VISUAL ASAM ASETAT (IVA) DENGAN PEMERIKSAAN IVA UNTUK DETEKSI DINI KANKER SERVIKS DI DESA DURIN SIMBELANG KABUPATEN DELI SERDANG
}

\author{
Lindawati Simorangkir* \\ Staf Pengajar STIKes Santa Elisabeth Medan*
}

\begin{abstract}
Background: Cervical cancer is a disease that ranked first cause of morbidity and mortality of women in Indonesia. In Durin Simbelang Village District Deli Serdang, from 100 women who tested with IVA as $2 \%$ positive for cervical cancer (higher than Glocoban International Agency Reasearch on Cancer estimates that is 0,016\%). Early detection of cervical cancer can be done for free at the health center by using Visual Inspection with Acetate Acid (IVA)

Goal: This study aims to determine the relationship perception of seriousness with the visual inspection with acetate acid test in Pancur batu.

Methods The type of research was explanatory survey that aimed to analyze the relationship perception of seriousness on the visual inspection with acetate acid test. The population were 794 women of the reproductive age couples in Pancur Batu and the sample of 90 people were taken by simple random sampling technique. Data were analyzed using chi-square test on the level of $95 \%$.

Result: The results of research showed that variables which had relation with the visual inspection with acetate acid.

Conclusion: Base on the result of research, it is suggested to IVA officer at the health centre to perform more intensive and continuous promotion about IVA by using methods and tools which easily understood by the women, and also coordinating with cadres and the leaders of religious meeting who could persuade women to do IVA test.
\end{abstract}

\section{Keywords: Perception, Visual Inspection with Acetate Acid}

\section{PENDAHULUAN}

Perubahan pola perilaku dan gaya hidup masyarakat serta perubahan lingkungan tanpa disadari telah memberikan pengaruh terhadap terjadinya kecenderungan baru dalam pola penyakit yang ada di masyarakat. Selain penyakit menular, saat ini perhatian terhadap penyakit tidak menular juga semakin meningkat karena tingginya frekuensi kejadiannya di masyarakat.

Salah satu penyakit tidak menular yang hingga saat ini masih menjadi penyakit yang mematikan di dunia dengan jumlah penderita yang terus meningkat 
dari tahun ke tahun adalah penyakit kanker. Di dunia, $12 \%$ dari seluruh kematian disebabkan oleh kanker dan kanker merupakan pembunuh nomor 2 setelah penyakit kardiovaskular. WHO dan Bank Dunia memperkirakan setiap tahun sekitar 12 juta orang di seluruh dunia menderita kanker dan 7,6 juta di antaranya $(63,3 \%)$ meninggal dunia. Jika tidak dikendalikan, diperkirakan 26 juta orang akan menderita kanker dan 17 juta $(65,3 \%)$ di antaranya meninggal dunia karena kanker pada tahun 2030. Ironisnya, kejadian ini akan terjadi lebih cepat di negara miskin dan berkembang (Depkes RI, 2009).

Dari 15 kanker terbanyak di dunia, 3 di antaranya adalah kanker ginekologik yaitu kanker serviks, kanker ovarium dan kanker uterus. Dalam distribusi kanker ginekologik secara epidemiologi kanker serviks menempati urutan pertama dengan angka harapan hidup 5 tahun (five-years expecetancy rate) adalah 53,5\%.

Berdasarkan data Glocoban, International Agency for Research on Cancer (2002), kanker serviks menempati urutan kedua dari seluruh kanker pada perempuan dengan insiden rate 16 per 100.000 perempuan, kasus baru yang ditemukan 9,7\% dengan jumlah kematian 9,3\% per tahun dari seluruh kanker pada perempuan di dunia (Depkes RI, 2009).

Di Asia, kanker serviks merupakan penyakit kanker pada wanita kedua terbanyak diderita dan lebih dari setengah wanita Asia yang menderita kanker serviks meninggal dunia. Ini sama dengan 22.6000 wanita yang didiagnosa menderita kanker serviks dan sebanyak 143.000 penyebab kematian atau dengan kata lain setiap 4 menit, seorang wanita di Asia Pasifik meninggal karena kanker serviks (Depkes RI, 2009).

Di Indonesia angka kesakitan dan kematian karena kanker serviks menempati peringkat pertama atau tertinggi. Berbeda dengan di negara maju, kanker payudara yang menempati peringkat pertama. Jumlah penderita kanker payudara di Indonesia mungkin sama banyaknya dengan penderita di luar negeri. Hanya saja jumlah penderita kanker serviks di Indonesia menjadi sangat luar biasa banyaknya sehingga dapat melampaui banyaknya jumlah penderita kanker payudara (Kontras, 2009).

Berdasarkan data Sistem Informasi Rumah Sakit (SIRS) Indonesia tahun 2007, kejadian kanker serviks mencapai 5.786 kasus atau $11,78 \%$. Kejadian kanker serviks ini meningkat dari jumlah kasus pada 2006 yang sebanyak 4.696 kasus atau $11,07 \%$. Data dari Yayasan Kanker Indonesia (YKI) tahun 2007 juga menyebutkan, setiap hari jumlah pasien kanker serviks bertambah 41 kasus baru, dan 20 di antaranya meninggal dunia. Setiap tahun sekitar 500.000 perempuan di Indonesia didiagnosis terinfeksi kanker serviks. Dari jumlah itu, sekitar 270.000 penderita meninggal dunia atau dengan kata lain setiap satu jam, seorang perempuan di Indonesia meninggal karena kanker serviks.

Menurut Yayasan Kanker Indonesia (YKI), tingginya angka kasus penyakit kanker serviks terutama disebabkan kurangnya kesadaran untuk melakukan deteksi dini sehingga sebagian besar penderita diketahui sudah dalam keadaan stadium tinggi (Sriwijaya Post, 2010).

Berdasarkan data WHO tahun 2004, lebih dari 50\% perempuan penderita 
kanker tidak pernah melakukan deteksi dini kanker (Waspada, 2009). Menurut data BKKBN tahun 2007, besarnya jumlah penderita kanker disebabkan karena kesadaran wanita untuk memeriksakan diri masih sangat rendah dan lebih dari $70 \%$ penderita yang datang ke rumah sakit sudah dalam stadium lanjut.

Program deteksi dini kanker serviks dapat dilakukan dengan beberapa cara, antara lain teknik Pap Smear, kolposkopi, servikografi, pap net, maupun Inspeksi Visual dengan Asam Asetat (IVA). Di negara-negara maju, Pap Smear telah terbukti menurunkan kejadian kanker serviks invasif sebesar 46-76\% dan mortalitas kanker serviks sebesar 50-60\%. Bahkan di Amerika Serikat Pap Smear telah terbukti efektif dalam mencegah kanker serviks hingga mencapai $93 \%$.

Berbeda dengan di Indonesia, cakupan deteksi dini kanker serviks seperti Pap Smear masih rendah. Berdasarkan estimasi WHO tahun 2008, terdapat hanya $5 \%$ wanita di negara-negara berkembang termasuk Indonesia yang melakukan pemeriksaan Pap Smear, sedangkan di negara-negara maju hampir $70 \%$ wanita telah melaksanakan Pap Smear.

Rendahnya cakupan metode deteksi dini kanker serviks dengan menggunakan Pap Smear ini antara lain disebabkan karena luasnya wilayah negara yang terdiri dari beribu pulau dan juga kurangnya sumber daya manusia sebagai pelaku skrining, khususnya kurangnya tenaga ahli patologik anatomik/sitologi dan teknisi sitologi/skriner. Oleh karena itu maka beberapa pakar dan organisasi kesehatan bekerjasama dengan Kementerian Kesehatan Republik Indonesia membuat terobosan inovatif cara mendeteksi dini kanker rahim melalui metode Inspeksi
Visual dengan Asam Asetat (Kemenkes RI, 2010).

Mendeteksi dini kanker serviks menggunakan metode IVA cukup dengan cara mengoleskan asam asetat atau asam cuka pada serviks dan dalam waktu 10 menit dapat diketahui hasilnya melalui bercak putih yang dihasilkan oleh lesi prakanker. Dengan metode IVA, pemeriksaan dini kanker serviks dapat dilakukan di puskesmas biasa dan dapat dilakukan oleh bidan-bidan yang telah diberi pelatihan.

Berdasarkan Laporan Subdit Kanker Kementerian Kesehatan RI tahun 2008 , terlihat bahwa rata-rata pencapaian skrining kanker serviks untuk target 5 tahun adalah $11,64 \%$. Pencapaian ini masih lebih rendah dari target tahunan sebesar 20\%. Oleh karena itu diperlukan upaya promosi yang lebih intensif agar target $20 \%$ setahun (100\% dalam 5 tahun) dapat tercapai. Program deteksi dini kanker serviks mempunyai target $80 \%$ perempuan usia 30-50 tahun melakukan skrining sehingga diharapkan terhindar dari kedua kanker tersebut. Pada tahun 2014 Kementerian Kesehatan menargetkan $25 \%$ kabupaten/kota di Indonesia akan melaksanakan deteksi dini kanker serviks dengan IVA.

Menurut Dirjen Pengendalian Penyakit dan Penyehatan Lingkungan (P2PL) Kementerian Kesehatan RI, persoalan dan hambatan yang dihadapi dalam upaya pencegahan kanker adalah adanya persepsi masyarakat tentang kanker yang tidak benar seperti kanker tidak dapat disembuhkan, penyakit yang memalukan, dan percaya terhadap klenik dalam pengobatan kanker. Masyarakat masih mempersepsikan kanker sebagai penyakit mematikan, tidak dapat disembuhkan, dan 
tidak dapat dicegah serta memerlukan biaya yang tinggi untuk pengobatannya Di samping itu, kurangnya kesadaran masyarakat dalam mencegah kanker sedini mungkin (Kompas, 2010).

Menurut Yayasan Kanker Indonesia (2008), budaya dan adat ketimuran di Indonesia telah membentuk sikap dan persepsi yang jadi penghalang bagi perempuan untuk membuka diri kepada profesional medis dan berdaya diri melindungi kesehatan reproduksinya. Akibatnya, lebih dari $70 \%$ penderita kanker serviks datang untuk berobat ketika keadaan kesehatannya telah kritis, dan penyakit kanker ditemukan dalam stadium lanjut hingga sulit diobati.

Persepsi adalah pengalaman tentang objek, peristiwa, atau hubunganhubungan yang diperoleh dengan menyimpulkan informasi dan menafsirkan pesan (Rakhmat, 2007). Persepsi adalah pengalaman yang dihasilkan melalui indra penglihatan, pendengaran, penciuman, dan sebagainya. Setiap orang mempunyai persepsi yang berbeda, meskipun objeknya sama. Perubahan-perubahan perilaku dalam diri seseorang yang dapat diketahui melalui persepsi. Oleh sebab itu indikator perilaku kesehatan sangat berkaitan dengan persepsi (Notoatmodjo, 2007).

Menurut teori Health Belief Model yang dikemukakan oleh Hochbaum, Rosenstock, Kasl dan Cobb, kemungkinan individu melakukan tindakan pencegahan tergantung secara langsung pada hasil dari dua keyakinan atau penilaian kesehatan (health beliefs) yaitu ancaman yang dirasakan serta sakit dan pertimbangan keuntungan dan kerugian. Penilaian dilihat dari persepsi kerentanan penyakit, persepsi keseriusan penyakit, persepsi manfaat dan persepsi rintangan yang dirasakan. (Muhazam, 1995).

Penelitian yang dilakukan oleh

Jepson di Amerika Serikat (2000) menemukan adanya hubungan yang kuat antara persepsi rintangan dengan tindakan tidak mendeteksi dini kanker leher rahim. Rintangan yang dirasakan oleh para wanita dalam mendeteksi dini kanker leher rahim adalah rasa malu, rasa takut akan hasil deteksi dini dan rasa sakit dari tes yang dilakukan.

Menurut penelitian Yusida (2006) faktor yang berhubungan dengan partisipasi wanita dalam program skrining kanker leher rahim antara lain adalah persepsi wanita itu sendiri. Wanita yang mempunyai persepsi penyakit kanker leher rahim sebagai penyakit yang serius mempunyai kecenderungan melakukan skrining sebesar 5 kali dibanding yang tidak memiliki persepsi keparahan yang serius.

Menurut penelitian Sari (2008), persepsi wanita merupakan salah satu faktor yang berhubungan dengan perilaku wanita dalam pemeriksaan deteksi dini kanker serviks. Menurut penelitian Yuli (2010), variabel yang berpengaruh secara signifikan terhadap pemanfaatan pelayanan IVA adalah variabel persepsi keseriusan penyakit, persepsi kerentanan diri dan persepsi rintangan.

Di Sumatera Utara, Rumah Sakit Umum Pusat Haji Adam Malik Medan merupakan rumah sakit rujukan untuk penderita kanker serviks. Jumlah penderita kanker serviks pada tahun 1998-2002 sebanyak 421 orang, pada tahun 20032007 meningkat menjadi 492 orang dan pada tahun 2008-2009 tercatat sudah sebanyak 176 orang penderita (Daulay, 2011). 
Menurut Dinas Kesehatan Kabupaten Deli Serdang, program IVA sudah berjalan sejak tahun 2009. Program ini merupakan program dari Dinas Kesehatan Propinsi dan melalui Dinas Kesehatan Kabupaten diteruskan hingga ke Puskesmas. Untuk pelaksanaan program ini telah dilakukan pelatihan kepada bidan ataupun perawat Puskesmas sebanyak 2 kali pada tahun 2009, sehingga kegiatan IVA sudah bisa dilakukan di Puskesmas.

Kegiatan penyuluhan dan pemeriksaan IVA telah dilakukan di 28 wilayah kerja puskesmas di Kabupaten Deli Serdang. Pada tahun 2014 telah dilakukan pemeriksaan pada 4354 wanita pasangan usia subur dan diperoleh hasil sebanyak 37 orang wanita positif menderita penyakit kanker serviks.

Pada bulan April tahun 2014, telah dilakukan penyuluhan tentang pentingnya deteksi dini kanker serviks dengan metode IVA di DesaDurin Simbelang, dari hasil penyuluhan itu sebanyak 100 orang wanita pasangan usia subur bersedia menjalani pemeriksaan IVA, dan ternyata sebanyak 2 orang $(2 \%)$ dinyatakan positif menderita kanker serviks dan dirujuk ke RSUP Haji Adam Malik untuk mendapatkan pengobatan. Hal ini lebih tinggi dari estimasi Glocoban IARC (2002) yaitu 16 per 100.000 perempuan $(0,016 \%)$.

Menurut petugas pelayanan IVA di Puskesmas Kecamatan Pancur Batu, umumnya alasan para wanita pasangan usia subur tersebut tidak mau melakukan pemeriksaan IVA antara lain adalah mereka menganggap tidak perlu melakukan pemeriksaan karena perilaku seksual mereka baik dan tidak bergantiganti pasangan, selain itu ada perasaan malu karena harus diperiksa organ intimnya dan ada juga yang merasa takut kalau ternyata hasil pemeriksaannya nanti tidak normal.

Berdasarkan uraian di atas maka peneliti ingin meneliti tentang Hubungan persepsi keseriusan penyakit wanita pasangan usia subur tentang Inspeksi Visual Asam Asetat (IVA) dengan pemeriksaan IVA untuk deteksi dini kanker serviks di Desa Durin Simbelang Kecamatan Pancur Batu Kabupaten Deli Serdang.

Tujuan Penelitian ini adalah menganalisis hubungan $h$ persepsi keseriuasan penyakit wanita pasangan usia subur tentang Inspeksi Visual Asam Asetat (IVA) dengan pemeriksaan IVA untuk deteksi dini kanker serviks di Desa Durin Simbelang Kecamatan Pancur Batu Kabupaten Deli Serdang.

\section{HASIL PENELITIAN}

Tabel 1. Distribusi Karakteristik Responden di Desa Durin Simbelang Kecamatan Pancur Batu Kabupaten Deli Serdang Tahun 2015

\begin{tabular}{|c|c|c|}
\hline Karakteristik & $\mathbf{f}$ & $\%$ \\
\hline \multicolumn{3}{|l|}{ Umur (tahun) } \\
\hline $30-35$ & 21 & 23,3 \\
\hline $36-49$ & 69 & 76,7 \\
\hline Total & 90 & 100 \\
\hline \multicolumn{3}{|l|}{ Pendidikan } \\
\hline $\mathrm{SD}$ & 9 & 10,0 \\
\hline SMP & 17 & 18,9 \\
\hline SMU & 48 & 53,3 \\
\hline Diploma/Sarjana & 16 & 17,8 \\
\hline
\end{tabular}




\begin{tabular}{lrr}
\hline \multicolumn{1}{c}{ Total } & $\mathbf{9 0}$ & $\mathbf{1 0 0}$ \\
\hline Pekerjaan & 19 & 21,1 \\
PNS/POLWAN & 3 & 3,3 \\
Wiraswasta/Karyawan Swasta & 68 & 75,6 \\
Ibu rumah tangga & & \\
\hline \multicolumn{1}{c}{ Total } & $\mathbf{9 0}$ & $\mathbf{1 0 0}$ \\
\hline
\end{tabular}

Tabel 2. Distribusi Responden Berdasarkan Kategori Persepsi Keseriusan Penyakit di Desa Durin Simbelang Kecamatan Pancur Batu Kabupaten Deli Serdang Tahun 2015

\begin{tabular}{lcc}
\hline $\begin{array}{c}\text { Persepsi } \\
\text { Keseriusan } \\
\text { Penyakit }\end{array}$ & f & $\%$ \\
\hline Baik & 75 & 83,3 \\
Sedang & 15 & 16,7 \\
\hline \multicolumn{1}{r}{ Total } & $\mathbf{9 0}$ & $\mathbf{1 0 0 , 0}$ \\
\hline
\end{tabular}

Tabel 3. Distribusi Responden Berdasarkan Pemeriksaan IVA di Desa Durin Simbelang Kecamatan Pancur Batu Kabupaten Deli Serdang Tahun 2015

\begin{tabular}{|c|c|c|}
\hline $\begin{array}{c}\text { Pemeriksaan } \\
\text { IVA }\end{array}$ & f & $\%$ \\
\hline Ya & 32 & 35,6 \\
\hline Tidak & 58 & 64,4 \\
\hline Total & 90 & 100,0 \\
\hline
\end{tabular}

Tabel 4. Hubungan Persepsi Keseriusan Penyakit dengan Pemeriksan IVA di Desa Durin Simbelang Kecamatan Pancur Batu Kabupaten Deli Serdang Tahun 2015

\begin{tabular}{lrrrrrrr}
\hline Persepsi & \multicolumn{4}{c}{ Pemeriksaan IVA } & \multicolumn{2}{c}{ Total } & \multirow{2}{*}{ P } \\
\cline { 2 - 6 } Keseriusa & \multicolumn{2}{c}{ Ya } & \multicolumn{2}{c}{ Tidak } & \multicolumn{2}{c}{ Valu } \\
\cline { 2 - 6 } n Penyakit & $\mathbf{n}$ & $\mathbf{\%}$ & \multicolumn{1}{c}{ n } & \% & n & \% & $\boldsymbol{e}$ \\
\hline Baik & 25 & 33 & 50 & 67 & 75 & 100 & 0,325 \\
Sedang & 7 & 47 & 8 & 53 & 15 & 100 &
\end{tabular}

Berdasarkan hasil penelitian diketahui bahwa persepsi keseriusan penyakit responden sebagian besar berada pada kategori baik, yaitu sebanyak 75 responden $(83,3 \%)$. Dari tabulasi silang dapat dilihat bahwa dari 75 responden yang memiliki persepsi keseriusan penyakit kategori baik, sebesar 33,3\% telah melakukan pemeriksaan IVA. Namun hasil uji chi-square memperlihatkan bahwa tidak terdapat hubungan antara persepsi keseriusan penyakit dengan pemeriksaan IVA. Hal ini ditunjukkan dari nilai $\mathrm{p}=0,325$ ( $\mathrm{p}>0,05)$, sehingga tidak bisa dimasukkan dalam uji multivariat dengan regresi logistik berganda.

\section{PEMBAHASAN}

\section{Persepsi Keseriusan Penyakit}

Berdasarkan hasil penelitian diketahui bahwa persepsi keseriusan penyakit responden sebagian besar berada pada kategori baik, yaitu sebanyak 75 responden $(83,3 \%)$.

Hal ini tidak sesuai dengan teori Health Belief Model yang dikemukakan oleh Rosenstock dalam Muzaham (1995) yang menyatakan bahwa kesiapan seseorang untuk melakukan suatu tindakan ditentukan oleh pandangan orang itu terhadap bahaya penyakit tertentu dan persepsi mereka terhadap kemungkinan akibat (fisik dan sosial) bila terserang penyakit tersebut. Rosenstock juga mengemukakan bahwa tindakan individu untuk mencari pengobatan atau pencegahan penyakit akan didorong oleh persepsi keseriusan terhadap penyakit. Individu akan bertindak melawan atau mengobati penyakit bila ia termotivasi oleh keseriusan penyakit yang dirasakannya.

Hal ini juga tidak sesuai dengan penelitian Yuli (2010) yang mengungkapkan bahwa terdapat hubungan yang signifikan antara persepsi keseriusan 
penyakit kanker serviks dengan pemanfaatan pelayanan IVA.

Berdasarkan hasil penelitian didapatkan bahwa sebagian besar responden telah mempersepsikan kanker serviks sebagai penyakit yang serius dan mengancam kehidupan wanita, akan tetapi persepsi yang baik ini tidak membuat mereka langsung memutuskan untuk melakukan pemeriksaan IVA, karena sebagian merasakan adanya hambatanhambatan seperti rasa malu, rasa takut untuk menjalani pemeriksaan IVA, dan sebagian lagi merasa tidak berisiko untuk terserang kanker serviks karena selama ini tidak memiliki gejala apa pun, sehingga merasa tidak perlu melakukan pemeriksaan IVA.

\section{Pemeriksaan IVA}

Berdasarkan hasil penelitian diketahui bahwa pemeriksaan IVA responden sebagian besar berada pada kategori tidak, yaitu sebanyak 58 responden $(64,4 \%)$.

Menurut Health Belief Model walaupun seseorang yakin bahwa dirinya rentan terhadap suatu penyakit, dan juga sudah mengetahui bahaya tersebut, ia tidak akan begitu saja menerima tindakan kesehatan yang dianjurkan kepadanya, individu itu akan mempertimbangkan apakah alternatif itu bermanfaat dapat mengurangi ancaman penyakit atau tidak.

Berdasarkan hasil penelitian didapatkan bahwa ternyata masih ada responden yang beranggapan kalau pemeriksaan IVA belum tentu dapat mencegah kanker serviks dan jika ternyata hasilnya positif maka sulit untuk diobati dan kemungkinan sembuh sangat kecil. Ada juga beberapa responden yang tidak mengetahui manfaat pemeriksaan IVA ini karena kurangnya informasi tentang hal tersebut. Berdasarkan hasil wawancara dengan petugas IVA di Puskesmas Pancur Batu, diketahui bahwa sosialisasi tentang program IVA gratis di Puskesmas umumnya dilakukan di pengajian ibu-ibu yang ada di masing-masing lingkungan, akan tetapi ternyata tidak semua ibu-ibu tersebut dapat hadir di pengajian karena berbagai kesibukan. Oleh karena itu sebaiknya upaya penyuluhan dan promosi tentang pemeriksaan IVA ini lebih ditingkatkan lagi, tidak sebatas di dalam pengajian saja, akan tetapi juga disampaikan di luar pengajian sehingga dapat meningkatkan persepsi ibu-ibu tentang manfaat pemeriksaan IVA untuk deteksi dini kanker serviks.

\section{Hubungan Persepsi Keseriusan Penyakit dengan Pemeriksaan IVA}

Dari tabulasi silang dapat dilihat bahwa dari 75 responden yang memiliki persepsi keseriusan penyakit kategori baik, sebesar 33,3\% telah melakukan pemeriksaan IVA. Namun hasil uji chisquare memperlihatkan bahwa tidak terdapat hubungan antara persepsi keseriusan penyakit dengan pemeriksaan IVA. Hal ini ditunjukkan dari nilai $\mathrm{p}=0,325(\mathrm{p}>0,05)$.

Hal ini sejalan dengan teori Health Belief Model yang mengatakan bahwa seseorang akan bertindak untuk mencegah penyakit, apabila ia merasa keseriusan terhadap penyakit tersebut. Dengan perkataan lain, suatu tindakan pencegahan terhadap suatu penyakit akan timbul bila seseorang telah merasakan bahwa dirinya atau keluarganya rentan/berisiko untuk terserang penyakit tersebut.

Hasil penelitian ini sejalan dengan penelitian Patricia Bessler, Maung Aung,dan Pauline Jolly yang dilakukan di Trelawny, Jamaika (2005) yang menyatakan bahwa wanita yang merasa 
dirinya lebih berisiko terhadap kanker serviks cenderung telah melakukan deteksi dini kanker serviks dibandingkan dengan mereka yang merasa tidak berisiko. Hasil penelitian ini sesuai dengan penelitian Yuli (2010) yang menyatakan bahwa ada hubungan bermakna antara keseriusan penyakit dengan kanker serviks yang dirasakan oleh wanita dengan tindakan deteksi dini kanker serviks.

Berdasarkan hasil penelitian didapatkan bahwa ternyata ada beberapa responden yang masih belum mengetahui faktor-faktor risiko kanker serviks sehingga mereka menganggap bahwa dirinya tidak rentan terhadap kanker serviks. Masih ada responden yang berpendapat bahwa wanita berusia lebih dari 35 tahun tidak berisiko terkena kanker serviks karena mereka membuktikan bahwa mereka sendiri tidak terserang kanker serviks dan mereka melihat bahwa orang tua/ibu mereka atau wanita-wanita yang lebih tua di sekitar mereka tidak menderita kanker serviks.

Hal ini sejalan dengan pendapat Notoatmodjo (2005), persepsi dipengaruhi oleh pengalaman-pengalaman orang tersebut. Pengalaman disini meliputi pengalaman sehat-sakit. Orang sehat cenderung sulit untuk berpartisipasi dalam program kesehatan. Hal ini dipengaruhi oleh pengetahuan dan konsep sehat sakit yang dimilikinya yang umumnya berasal dari pengalaman pribadi maupun pengalaman orang-orang disekitarnya.

Hasil penelitian juga menunjukkan sebagian responden berpersepsi bahwa merokok tidak merupakan faktor risiko untuk terserang kanker serviks dan sebagian dari responden juga setuju bahwa penyakit kanker serviks umumnya diderita oleh wanita tuna susila yang sering berganti-ganti pasangan, oleh karena itu mereka merasa aman-aman saja karena selalu setia kepada pasangannya.

Menurut Rosenstock dalam Noorkasiani (2007) pendapat subjektif inilah yang merupakan kunci dari dilakukannya atau dihindarinya suatu tindakan kesehatan, artinya individu akan melakukan suatu tindakan untuk mencegah penyakit jika ia benar-benar merasa terancam oleh penyakit tersebut. Jika tidak, ia tidak akan melakukan tindakan apa pun.

Berdasarkan uraian di atas, perlu dilakukan upaya untuk meningkatkan persepsi kerentanan diri terhadap penyakit kanker serviks, antara lain bisa dilakukan dengan penyuluhan yang lebih intensif dan berkesinambungan oleh petugas IVA di puskesmas dalam menyampaikan faktorfaktor risiko serta siapa yang paling berisiko untuk menderita kanker serviks kepada para ibu, sehingga persepsi yang salah tentang hal ini bisa diatasi.

\section{KESIMPULAN}

Berdasarkan hasil penelitian dan pembahasan dapat diambil beberapa kesimpulan sebagai berikut:

1. Persepsi keseriusan penyakit wanita pasangan usia subur tentang Inspeksi Visual Asam Asetat (IVA) sebagian besar katagori baik sebanyak 75 $(83,6 \%)$.

2. Pemeriksaan IVA untuk deteksi dini kanker serviks sebagian besar tidak melakukan sebanyak $58(64,4 \%)$.

3. Ada hubungan antara variabel persepsi keseriusan penyakit dengan pemeriksaan IVA dengan nilai $\mathrm{p}=0,325$ $(\mathrm{p}>0,05)$ 
SARAN

Berdasarkan kesimpulan di atas, maka dapat diberikan saran atau rekomendasi sebagai berikut :

1. Kepada Puskesmas Pancur Batu agar lebih intensif dan berkesinambungan melakukan penyuluhan tentang pemeriksaan IVA untuk meningkatkan persepsi wanita pasangan usia subur tentang pentingnya pemeriksaan IVA.

2. Pemeriksaan IVA di Puskesmas sebaiknya dilakukan di ruangan yang privasi sehingga kenyamanan ibu tidak terganggu saat pemeriksaan dilakukan. Selain itu sebaiknya pemeriksaan IVA dilakukan oleh petugas kesehatan wanita untuk menghindari perasaan malu pada ibu.

\section{DAFTAR PUSTAKA}

Bessler P, Aung M, Jolly P. Factors Affecting Uptake of Cervical Cancer Screening Among Clinic Attendees in Trelawny, Jamaica. Cancer Control October 2007 ; 396-404.

Daulay, Ayu Sasmita, 2011. Hubungan Antara Karakteristik Individu dengan Stadium Klinis Kanker Serviks di RSUP Haji Adam Malik Medan Tahun 2008-2009.

Diananda, Rama, 2007. Mengenal Seluk Beluk Kanker, Yogyakarta : Katahati.

DiClemente, Peterson, 1994. AIDS Prevention and Mental Health, Preventing AIDS Theories and Methods of Behavioral Interventions, New York : Plenum Press.
Kementrian Kesehatan RI, 2010. Keputusan Menteri Kesehatan Republik Indonesia No.796/Menkes/SK/VII/2010 tentang Pedoman Teknis Pengendalian Kanker Payudara dan Kanker Leher Rahim. (http://www.hukor.depkes.go.id).

Maulana, Heri, 2007. Promosi Kesehatan. Jakarta : Penerbit Buku Kedokteran ECG.

Noorkasiani, 2007. Sosiologi Keperawatan. Jakarta : Penerbit Buku Kedokteran ECG.

Notoatmodjo, Soekidjo, 2007. Promosi Kesehatan dan Imu Perilaku, Jakarta : Rineka Cipta.

Nuranna, Laila, 2001. Skrining Kanker Serviks dengan Metode Skrining Alternatif : IVA, Cermin Dunia Kedokteran No.133 : 22-24.

Rakhmat, Jalaluddin, 2007. Psikologi Komunikasi. Cetakan kedua puluh empat - Januari, Bandung : PT. Remaja Rosdakarya.

Sukardja, Dewa Gede, 1996. Onklologi Klinik, Cetakan Pertama, Surabaya : Airlangga University Press.

Sunaryo, 2002. Psikologi untuk Keperawatan, Jakarta : Penerbit Buku Kedokteran ECG.

Thoha, Miftah, 2007. Perilaku Organisasi Konsep Dasar dan Aplikasinya. Jakarta : PT. Raja Grafindo Persada.

Widodo, Edi, 2011. Beberapa Faktor yang Berhubungan dengan Praktik Wanita Pekerja Seks dalam Pencegahan Infeksi Menular Seksual dan HIV \& AIDS di Lokalisasi Koplak Kabupaten Grobogan, Universitas Diponegoro Semarang 
(http://www.scribd.com/doc/

37834776/).

Winarno, 2008. Faktor-Faktor yang Berhubungan dengan Penggunaan Jarum Suntik bergantian di antara Pengguna Napza Suntik di Kota Semarang, Jurnal Promosi Kesehatan Indonesia Vol.3 No.2, 2008.

Yuli, Ellina, 2010. Pengaruh Persepsi Wanita Pasangan Usia Subur (Pus) Tentang Kanker Leher Rahim (Klr) Dan Program Inspeksi Visual Asetat (Iva) Terhadap Pemanfaatan
Pelayanan Iva Di Wilayah Kerja Puskesmas Bandar Khalifah Kecamatan Percut Sei Tuan Kabupaten Deli Serdang Tahun 2010 (www.repository.usu.ac.id, 2010).

Yusida, Ahdani, Hayati, 2006. Faktorfaktor yang Berhubungan dengan Partisipasi Wanita dalam Program Skrining Kanker Leher Rahim di Kota Banjarmasin, (http://www.risbinkes. litbang.depkes.go.id, 2006). 